\title{
Fibronectin Type III Domain-Containing Protein 5
}

National Cancer Institute

\section{Source}

National Cancer Institute. Fibronectin Type III Domain-Containing Protein 5. NCI

Thesaurus. Code C158412.

Fibronectin type III domain-containing protein 5 (212 aa, $\sim 24 \mathrm{kDa}$ ) is encoded by the human FNDC5 gene. This protein plays a role in the cellular response to physical reactivity. 